\title{
Inverse fly-through technique in ultrasound imaging of carotid stenosis
}

咸

Figure Intravessel view of carotid bifurcation

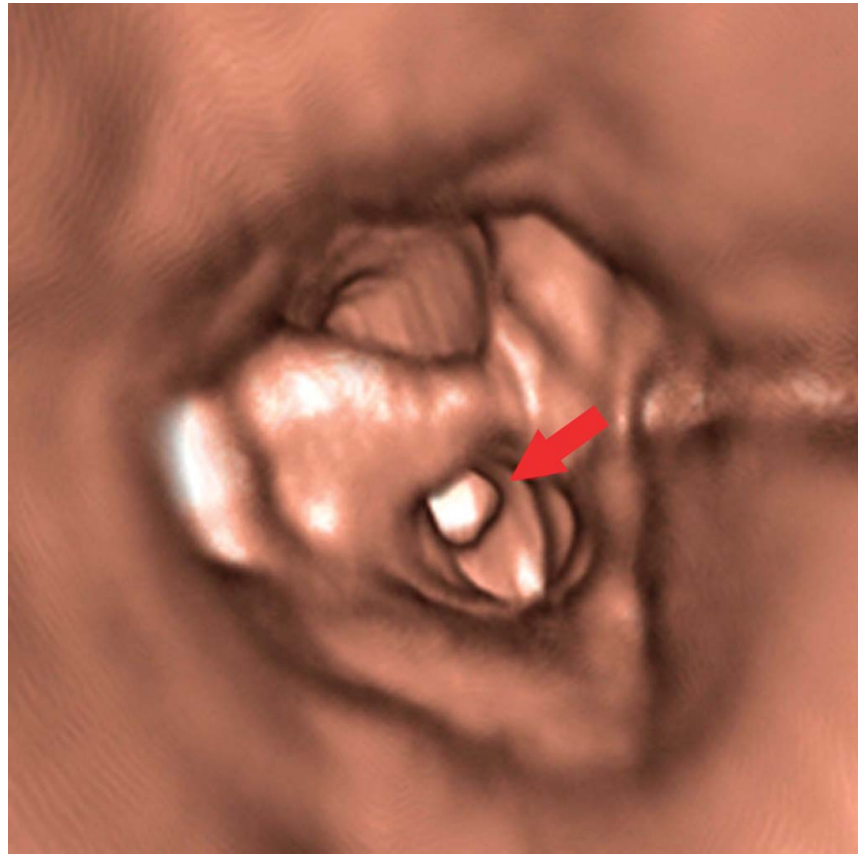

Arrow indicates moderate internal carotid artery stenosis.

A 58-year-old man presented for re-evaluation of an asymptomatic right-sided carotid stenosis. Besides conventional ultrasound techniques, we could confirm a moderate right internal carotid artery stenosis by the innovative inverse fly-through technique (figure). Regular checkups were initiated.

There is growing evidence that $3 \mathrm{D}$ ultrasound may provide new possibilities for evaluating carotid disease. ${ }^{1}$ With our technique, it is possible to view a carotid stenosis from all imaginable directions (video on the Neurology ${ }^{\circledR}$ Web site at www.neurology.org) and to provide patients with an easy-to-grasp presentation of their carotid stenosis. However, the reliability, validity, and clinical usefulness of the technique will require further study.

Hagen Kunte, MD, Ralph-Ingo Rückert, MD, PhD, Charlotte Schmidt, MS, Lutz Harms, MD, Maria Grigoryev, MD, Thomas Fischer, MD, Berlin, Germany

From the Department of Neurology (H.K., C.S., L.H.,), Institute of Radiology (M.G., T.F.), Charité-Universitätsmedizin Berlin; Department of Surgery (R.I.R.), Franziskus-Krankenhaus, Berlin, Germany.

Author contributions: Dr. Kunte, Dr. Rückert, M.S. Schmidt, Dr. Harms, Dr. Grigoryev, and Dr. Fischer: drafting/revising the manuscript, study concept and design, analysis and interpretation of data.

Supplemental data at www.neurology.org

Supplemental Data

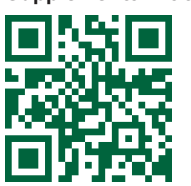

Study funding: No targeted funding reported.

Disclosure: The authors report no disclosures relevant to the manuscript. Go to Neurology.org for full disclosures.

Correspondence to Dr. Kunte: hagen.kunte@charite.de

1. Makris GC, Lavida A, Griffin M, Geroulakos G, Nicolaides AN. Three-dimensional ultrasound imaging for the evaluation of carotid atherosclerosis. Atherosclerosis 2011;219:377-383. 


\section{Neurology}

\section{Inverse fly-through technique in ultrasound imaging of carotid stenosis}

Hagen Kunte, Ralph-Ingo Rückert, Charlotte Schmidt, et al.

Neurology 2013;80;122

DOI 10.1212/WNL.0b013e31827b1b06

This information is current as of December 24, 2012

\begin{tabular}{|c|c|}
\hline $\begin{array}{l}\text { Updated Information \& } \\
\text { Services }\end{array}$ & $\begin{array}{l}\text { including high resolution figures, can be found at: } \\
\text { http://n.neurology.org/content/80/1/122.full }\end{array}$ \\
\hline Supplementary Material & $\begin{array}{l}\text { Supplementary material can be found at: } \\
\text { http://n.neurology.org/content/suppl/2012/12/23/80.1.122.DC1 }\end{array}$ \\
\hline References & $\begin{array}{l}\text { This article cites } 1 \text { articles, } 0 \text { of which you can access for free at: } \\
\text { http://n.neurology.org/content/80/1/122.full\#ref-list- } 1\end{array}$ \\
\hline Subspecialty Collections & $\begin{array}{l}\text { This article, along with others on similar topics, appears in the } \\
\text { following collection(s): } \\
\text { All Cerebrovascular disease/Stroke } \\
\text { http://n.neurology.org/cgi/collection/all_cerebrovascular_disease_strok } \\
\text { e } \\
\text { Ultrasound } \\
\text { http://n.neurology.org/cgi/collection/ultrasound }\end{array}$ \\
\hline Permissions \& Licensing & $\begin{array}{l}\text { Information about reproducing this article in parts (figures,tables) or in } \\
\text { its entirety can be found online at: } \\
\text { http://www.neurology.org/about/about_the_journal\#permissions }\end{array}$ \\
\hline Reprints & $\begin{array}{l}\text { Information about ordering reprints can be found online: } \\
\text { http://n.neurology.org/subscribers/advertise }\end{array}$ \\
\hline
\end{tabular}

Neurology ${ }^{\circledR}$ is the official journal of the American Academy of Neurology. Published continuously since 1951, it is now a weekly with 48 issues per year. Copyright @ 2012 American Academy of Neurology. All rights reserved. Print ISSN: 0028-3878. Online ISSN: 1526-632X.

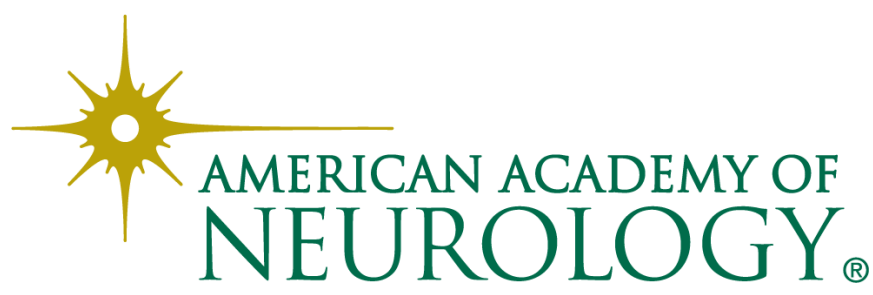

